Antonio Manieri*

\title{
The Law on Stables and Pastures: an Annotated Translation of the Kyūmokuryō (Sect. 23 of Yōrōryō)
}

\author{
https://doi.org/10.1515/asia-2019-0011
}

Abstract: This article proposes a translation of the Kyūmokuryō, or Law on Stables and Pastures, which is included in the Yōrō Era Code (718). It is the oldest extant text to systematically address only bovine and equine species, illustrating how the state protected, promoted, and enhanced their well-being. The Law provides the knowledge required to manage stables and pastures, from the allocation of tasks and duties of staff to feeding modalities (quantity, quality, and times of foraging, consumption of grass, salt, etc.), from annual animal marking and recording procedures to the treatment of illness, loss (and finding), death, mating, and calving/foaling, as well as how private animals may be exploited and the use of animals for military purposes. Historical commentaries and dictionaries have been a valuable resource in preparing the translation, and elements of animal welfare that are regarded as good practice even today are highlighted.

Keywords: Kyūmokuryō, ancient Japan, horses and bovines, animal welfare, Nara period

\section{Introduction}

\section{Ritsuryō state ideology and animal welfare in ancient Japan}

In eighth-century ritsuryō Japan, the state protected, promoted, and enhanced equine and bovine well-being by means of the Kyūmokuryō, ${ }^{1}$ or Law on Stables

1 For the title 厩牧令, I follow RR's reading Kyūmokuryō. This reading, which includes the kan'on pronunciation for 厩 and the go'on for 牧, is based on an interlinear gloss in katakana to the two characters 厩牧 recorded in the index of the Momijiyama Collection Manuscript. See RR: 735.

*Corresponding author: Antonio Manieri, Department of Asian, African, and Mediterranean Studies, “L’Orientale” University of Naples, Naples, Italy. E-mail: amanieri@unior.it 
and Pastures, here translated for the first time into English. ${ }^{2}$ It imposed precise rules on breeding and treating illness and disease, and the procedure to follow when livestock belonging to the two species die.

The Kyūmokuryō is Section 23 of the Yōrō ritsuryō (Yōrō Era Code), the large corpus of administrative and penal laws of the Nara period (710-784), completed in 718 as a revision of some previous codes, especially the Taihō ritsuryō (Taihō Era Code) of 701-702. The Yōrō Era Code was compiled under the direction of Minister Fujiwara no Fuhito (659-720), but it only entered into force in 757 under the reign of Kōken (718-770, r. 749-758, 764-770) and her minister Fujiwara no Nakamaro (706-764). The ritsu ("penal code") sections have largely been lost, but they have been reconstructed thanks to supplementary legislation. The ryō ("administrative code") sections have been reconstructed thanks to two main later commentaries including consistent quotations from the original, namely the Ryo no gige (Commentary on the Administrative Laws, 833, from now on: RGG) and the Ryō no shūge (Collected Commentaries on Administrative Laws, 859-877, from now on: RSG). There were some historical precursors of the Kyūmokuryō in the form of a number of regulations set out in the Taika edicts (646), and it also served as the main point of reference for subsequent legislation, in particular for those regulations later collected in the Engishiki (Regulations of the Engi Era, 927, from now on: ES) and the Ruiju sandaikyaku (Supplementary Laws of the Three Eras. Categorized, 11th C., from now on: RSDK), and some edicts recorded in the Shoku Nihongi (Annals of Japan. Continued, 797, from now on: SNG).

Overall, the Code establishes two different sets of regulations for the two species. Article 25 in the Shiki'inryō (Law on Officials) establishes the Hyōmeshi (Office for Military Horses), that depended on the Hyōbushō (Ministry for Military Affairs). It envisages one director, one secretary (third level officer), one senior clerk, and one junior clerk (fourth level officers), six servants, and one watchman. ${ }^{3}$ This Office was responsible for state horses (war horses), bovines, and managing provincial pastures (but not breeding animals in pastures), as well as private animals, and post stations. Article 63 establishes the Meryō (Bureau for Horses), divided into Sameryō and Umeryō, the Left and Right Divisions of the Bureau for Horses respectively, the bureau being directly dependent on the Daijōkan (Council of State). Each of the two divisions was run by one director, whose duties ranged from training and breeding, harnessing, feeding (forage, grass, cereals), to the registration of the animals of each member of the Umakaibe, the horse breeders corporation. Each director was

2 For a translation into German, see Dettmer 2010: 423-436.

3 RR: 172; Dettmer 2009: 235-236; Sansom 1932: 89. 
helped by one assistant director, one senior secretary, one junior secretary, one senior clerk, one junior clerk, two vets, sixty grooms, twenty servants, two watchmen, and a number of stableboys. ${ }^{4}$

Nevertheless, both the Meryō and the Hyōmeshi underwent a period of evolution during the eighth and the ninth centuries, the first of which was the establishment of the Naikyūryō (Bureau for Internal Stables) in $765 .^{5}$ This was considered to be the bureau for the horses of the monarch and the dynastic family, and, as such, it was regarded as a necessity, as was the centralization of military affairs after the Fujiwara no Nakamaro Rebellion. From 779 to 808 both bureaus were called Shūmeryō (Bureau for Horses), but the Naikyūryō, Shūmeryō, and Hyōmeshi were abolished in 808, and a new (Sau)meryō ${ }^{6}$ was set up. ${ }^{7}$

Of all the specific legislation on bovines, the only one to be cited in the Code is the Nyūko (or Chichiko: literally, the Household for Milk), regulating the breeding and milking of milk cows. It was established under article 44 of the Shiki'inryō on the Ten'yakuryō (Bureau for Medicine). ${ }^{8}$ In fact, as in all nonnomadic East Asia, milk was produced for therapeutic purposes rather than as ordinary food and it was also used for other dairy therapeutic products, such as so 蘇 (or 酥), and raku 酪. The ES includes the recipe for producing so, ${ }^{9}$ which consists of milk boiled down to one tenth of its volume, so that it becomes a product very similar to Mongol $\mathrm{ulm}$ and Chinese su. ${ }^{10}$ There are several references in Ishinpō (Essence of Medicine, 984), the earliest extant Japanese medical compilation, relating to the consumption of these products, in addition to some information in mokkan and officials' personal diaries. ${ }^{11}$ Moreover, a Council of State decree issued in 826 established the figure of the Nyū no chōjō (Head of Milk), in charge of dairy production. ${ }^{12}$ Lastly, a decree by the Council of State issued in 884 attests the Nyūgyūin (Palace for Milk Cows), ${ }^{13}$ a special office in

4 RR: 188; Dettmer 2009: 299-302; Sansom 1932: 99.

5 SNG Vol. 4: 70-71.

6 RSDK: 157-158.

7 On the evolution of these offices see Satō 1997: 130-142, and Satō 2016: 5-30, 215-238.

8 RR: 180-181; Dettmer 2009: 268-273; Sansom 1932: 94.

9 The same recipe is also included in Kuchizusami (Fun by Mouth, 970), a primer intended for memorization compiled by Minamoto no Tamenori (?-1011), in the section "Provinces". See KZ: 73-76.

10 See Kamo 1973: 630-634.

11 Satō 2016: 181-211.

12 RSDK: 162.

13 RSDK: 579. 
charge of seven milk cows and seven calves from the Miwara pasture in the province of Settsu. ${ }^{14}$

\section{The contents of Kyūmokuryō}

As suggested by the title, the Law consists of twenty-eight articles regulating stables and pastures. First of all, from the Law and its commentaries, a difference can be seen between raising animals in stables and in the field. Stables 厩 (Ch. jiu, Sino-Jp. $k u$ or $k y \bar{u}$ ) are called (m)umaya ${ }^{15}$ in the vernacular and are defined in both the RSG and the Wamyōruijushō (Classified Notes on Japanese Nouns, 933, from now on WMS) as “dwellings for bovines and horses”, even if older sources define them only as "horse stables". ${ }^{16}$ Pastures 牧 (Ch. mu, SinoJp. moku or boku) are known as maki in the vernacular and are defined as "fenced fields for animals in captivity" in the RSG. ${ }^{17}$ Later, in the Engishiki, raising animals inside the stable is referred to as tsunagigai 慗飼 (“on the tether”), and keeping livestock in pasture is called kunigai 国飼 (“in provinces"). ${ }^{18}$

However, the Kyūmokuryō not only regulates stables and pastures but is the main body of law establishing the system of post stations (eki 駅), one of the pivotal elements in the centralization of the state. ${ }^{19}$ Even if some mention of post stations occurs in early chronicles, systematic organization is first found in an edict issued in the second year of the Taika era (646) during the reign of Kōtoku (597-654, r. 645-654). It introduces the use of the "station bell” (ekirei 駅鈴) for the provision of horses. ${ }^{20}$ The Law regulates the

14 See also Satō 2016: 181-211.

15 The vernacular pronunciation of "horse" was uma during the Nara period and muma in the Heian period.

16 RSG: 915; WMS: 116.

17 RSG: 915; WMS: 6. In WMS the vernacular equivalent is mumaki, probably consisting of muma, "horse", and ki, meaning “enclosure", "fence” (城, 柵).

18 In the ES, Book 48 contains a more detailed introduction and nomenclature for the pastures, which are classified as "provincial pastures” (shokoku no maki 諸国牧), “pastures under royal control” (mimaki 御牧), and “pastures in the vicinity of the capital” (kinto no maki 近都牧). Book 28 of the ES also contains the list of pastures per province. Animals from the different types of pastures may be put to different uses. See ES: 973-984, 708-709. On the evolution of maki see also Yamaguchi 1986 and the recent Satō 2016: 5-60.

19 The first in-depth study of the post station system can be found in Sakamoto 1928, which has been a reference work for decades. A more recent study is Tanaami 1995.

20 NS: $280-281$. 
institution of post stations on state roads (ekiro 駅路), with one station every thirty miles. These depend on the Hyōmeshi but are run by the provinces in the person of a chief selected from the members of the "post station households" (yakko 駅戸). These chiefs are in charge of the station and the fields (ekiden 駅 田) around the station, essential for the production of rice (ekito 駅稲) used as food for guests and animals. The chief of the station is exempt from taxation and is responsible for the station (ekika 駅家) itself, including offices, rooms and refreshments (rice, sake) for guests, as well as stables, water wells, a storehouse, grooms, and equipment.

The Law sets out the essential requirements for the management of stables and pastures, regulating the working staff, their appointment, and their tasks and duties. Great emphasis is given to feeding (quantity, quality, and timing of providing forage, grass, salt, etc.) and procedures for the annual marking and registration of animals, the treatments of illness, loss (and finding), death, breeding and calving/foaling, and the private and military use of animals. Precise rules are also provided for the yearly ratios of newborns, dead heads, and adults per herd.

The Law is more specific with regard to horses than to bovines, of which only milk cows and calves are mentioned. Concerning horses at stations, the main distinction is between yakume (or ekiba) 駅馬 and denme (or denba) 伝馬. Yakume are post-station horses in the strict sense, also referred to as hayuma 早 馬 (“swift horses”) in pre-ritsuryō sources and in poetry. An example of such usage occurs in Traveller's Song 3439 from Book 14 of Man'yōshū (Collection for Myriads of Eras, post 759):

Suzu ga ne no From the rock-walled well

hayuma umaya no in the station where swift horses are, tsutsumii no ringing bells, mizu o tamahena give me water. imo ga tadate yo From your hands, my beloved. ${ }^{21}$

Even if the Law provides no information on the matter, the only officials who could make use of the post station system were those on official missions and in possession of the so-called "station bell", as the song describes. In addition, the number of yakume changed depending on the type of road: twenty for big roads, fourteen for medium, and five for small roads. ${ }^{22}$ Denme ("relais horses"), were looked after by specific households called denko 伝戸. Each district had five

21 MYS: 483.

22 ES Book 28 contains a detailed list of all the post stations in the early Heian period. ES: $711-717$. 
relais animals, all of which were state horses, located at the district headquarters. Unlike post horses, relais horses were also used by officials on non-official occasions, such as for the movements of provincial officials or the transfer of prisoners, and they could also be used along roads other than the ekiro.

\section{Chinese models and Japanese innovations}

The main model for the Kyūmokuryō is a similar law found in the Tang Codes: section 25 of the Tang ling (Tang Period Code) is in fact the Jiumu ling (Law on Stables and Pastures) and deals with animals. Actually, in previous codes, such as the Sui Dynasty Kaihuang Era Code (promulgated in 581) and its revisions, there is only one law embracing both stables and storehouses, subsequently divided into two separate laws, such as, for example, the Tang Code of the Third Year of the Kaiyuan Era (715). There are two main differences between the Tang and the Japanese Law on Stables and Pastures. ${ }^{23}$ First of all, the Tang law is not limited to horses and cattle as it also extends to camels, mules, donkeys, and sheep, as shown in the first article. Bovines are covered in greater detail in the law, as reflected by the more detailed sector-specific terminology pertaining to (milk) cows, male bovines, and calves. Secondly, the Tang Codes do not mention what appears to be a pivotal institution in ancient Japan: "relay horses".

There are two reasons for the Japanese restriction to horses and bovines. Firstly, some animals such as camels and donkeys, despite being known in ancient times, were not bred in Japan. ${ }^{24}$ Secondly, and more importantly, because of their social functions, and more so than any other animal species, horses and bovines had a special role in the ritsuryō state, due to their use in court ceremonies, for official transportation, for military purposes, and, most of all, as working animals. The centrality of equine and bovine species in old Japan is also demonstrated in ancient lexicography, where "horses and bovines" occupied a special section, totally distinct from the sections dedicated to other animals, and, as in the case of WMS, they were often included in a macro-area dealing with human activities.

The Law makes no mention of their role as working animals, but a 741 royal edict of Shōmu (701-756, r. 724-749) acknowledges the special importance of equines and bovines: “[...] horses and bovines work and toil in the place of men

23 The text is found in Niida 1964 [1933]: 697-712. For a comparison between Japanese Law and Tang Law see Ikeda 1997: 1379-1391.

24 Kamo 1973: 491, 683. 
and give them sustenance. Hence, it is prohibited, as already established in the past, to kill and butcher such beasts". ${ }^{25}$ As stated in the edict, this is not the first rule forbidding the killing of beasts or the consumption of their meat: in 674, the sovereign Tenmu (?-686, r. 673-686) had already ordered that "no one shall eat the flesh of bovines, horses, dogs, monkeys, or chickens; this prohibition does not extend to other kinds of meat; offenders against this regulation shall be punished." ${ }^{26}$ Art. 8 of the Kukoritsu (Penal Law on Stables and Storehouses) states that the punishment for killing horses and bovines is one year of penal servitude. Prohibitions against meat consumption in these edicts could be connected to some ritual practices showing Daoist and/or Buddhist aversion to blood sacrifices and meat eating. On the one hand, this seems to be linked to the emergence of "purity as a distinct politico-religious value", that Herman Ooms has dated at the end of Tenmu's rule. ${ }^{27}$ On the other hand, the Buddhist ethical concern about animals seems particularly evident in some stories of the Nihon ryōiki (Record of Miraculous Events in Japan, c. 823) set during Shōmu's reign. ${ }^{28}$ In any case, considering the reason given in Shōmu's edict itself regarding the value in which these two species were held by the ancient Japanese, I prefer to follow the trend in cultural anthropology whereby the taboo against eating horsemeat and beef is essentially due to the animals' utility. ${ }^{29}$

Other than as working animals, the two species are also useful for transportation. ${ }^{30}$ As already mentioned, the ritsuryō (and the Kyūmokuryō in particular) also regulate official transfers, establishing a very effective system of roads and post stations, subsequently confirmed and improved by later legislation, in particular the Engishiki. ${ }^{31}$ Moreover, horses were also useful in the military sphere. In fact, in addition to some notes on state horses used also as "war horses", the Gunbōryō (Law on Military Defence) states that "those skilled with bow and horse shall be allocated to cavalry companies" (art. 2) and that "packhorses shall be assigned to each campfire" (art. 5). ${ }^{32}$ Lastly, even if not

25 SNG Vol. 2: 386-387.

26 NS: 418-419.

27 Ooms 2009: 253-266.

28 As shown, for example, in stories 5 and 10 in Book 2 of the Nihon ryōiki. See NR: 65-68, 76-78, 231-232, 237.

29 See, for example Harris 1998. It should be stressed that if an edict prohibits a custom, it may be assumed that the custom is widespread. Hence, it may also be assumed that prior to the edict, the meat of equines and bovines was in fact eaten.

30 Oxen were used by the aristocracy.

31 Verschuer 2008.

32 RR: 319-320. Friday 2014: 1-2. On the use of horses in ancient Japanese cavalry, see, in general, Friday 1992, and Muraoka 1984. 
clearly stated in the Law, horses and bovines were also very common presences at rituals, ceremonies, shrines (e.g. at Ise), and horseraces (kurabe(m)uma) and were offered as tributes from provinces. ${ }^{33}$

Study of the Kyūmokuryō could thus be an essential step in reconstructing the role of horses and cattle in ancient Japan; it may also serve to enrich the discourse on the instruments put in place by the central government to enhance and guarantee the state stabilization project.

\section{About this translation}

The translation is based on the text of the Kyūmokuryō in the critical edition of the ritsuryō by Inoue Mitsusada's research team and included in the Nihon Shisō Taikei. ${ }^{34}$ Much use has been made of historical commentaries such as RGG and RSG, including several quotations from older commentaries, ${ }^{35}$ and of historical dictionaries, such as WMS.

Japanese and Chinese words appear in modernized transcriptions (a modified Hepburn system for Japanese and pinyin for Chinese) and do not take into account historical changes to words or Chinese tones. Sino-Japanese historical terms are sometimes given in both go'on and kan'on variants. However, in the translation I have avoided Japanese words as far as possible, providing any specific term or explanation in footnotes, with the exception of units of measurement, always expressed in their original Sino-Japanese form. Characters are provided when they constitute a useful argument and for some specific terms.

33 This is more evident in the long lists of rituals provided in Book 47 of the ES, requiring the presence of horses, but also in many other Heian period sources, from protocol manuals to court diaries and monogatari. As for the Nara period, there is no such assortment of attestations, but there are numerous examples in SNG, such as the "black stallions of Kai" used in rituals to avert drought held at the Niu shrine.

34 Indicated in this article by the acronym RR.

35 In particular: the Koki (Ancient Comment) is an anonymous commentary dating from the early eighth century; the Ryōshaku (Code Interpretation) is a commentary to the Yōro era Administrative Code probably compiled in the early years of the Enryaku era (782-806) by Iyobe no Yakamori (?-?), and it is also recorded in the Honchō hōka monjo mokuroku (Catalogue of Commentaries to Codes in Our Country, 11th C.); the Kekki (or Anaki) was compiled by unidentified scholar Anō in the late eighth century; the Shuki (Comments in Red Characters) dates from the early ninth century and was compiled by an anonymous author who added his exegesis on the main texts in red characters. 


\section{Translation}

\section{The law on stables and pastures}

Article 1. At each stable, one groom ${ }^{36}$ shall be assigned to each high-quality horse, two medium-quality horses, and three low-quality horses, ${ }^{37}$ and one stableboy $^{38}$ shall be assigned to each horse. Every day high-quality horses shall be given one $s h{ }^{39}$ of millet, three sho of rice, ${ }^{40}$ two sho of beans, ${ }^{41}$ and two shaku ${ }^{42}$ of salt ${ }^{43}$; medium-quality horses shall be given two shō of rice or beans and one shaku of salt; low-quality horses shall be given one shō of rice. Five sheaves of hay and two sheaves of tree leaves shall be given to each horse. (Each sheaf shall measure three shaku in circumference). Moreover, as for fresh grass, twice the amount of hay shall be given. Hay shall be given from the first decade of the eleventh month. Fresh grass shall be given from the first decade of

36 Chō (or tei) 丁. On the staff in Meryō (Bureau for Horses), see Introduction.

37 Horses are classified here into three categories: 細馬 saime, 中馬 chūme, and 駑馬 tome. Classifications of horses occur in several sources and both RGG and RSG record several attestations. In particular, one of the oldest appears to be a passage, quoted by RSG, from the chapter Xiaguan sima (Summer Offices) in Zhouli (Rites of Zhou, 250 BCE ca.), relating to the army, where a more detailed classification includes six types of horse: 辨六馬之屬、種馬一物、 戎馬一物、齊馬一物、道馬一物、田馬一物、駑馬一物。“We distinguish six different classes of horses: thoroughbred, war horses, elegant horses, road horses, burden horses, and weak horses” (RSG: 915). In Japan, the high-quality horse is referred to as 駿馬 in WMS, Ch. junma, Sino-Jp. shunme, whose vernacular equivalent is suguretaru uma ("excellent horse"), quoted from a gloss in Nihongi shiki (Private Notes on the Annals of Japan, 9th C.). On the other hand, the WMS uses the same compound for the low-quality horse as the Kyūmokuryō: tome, read as osoki uma ("slow horse") according to the Kangoshō (Notes on Chinese Nouns, early 8th C.) (WMS: 127). In addition, emphasis on the "good horse" (良馬, Sino-Jp. ryōba) also occurs in the Nihon shoki (Annals of Japan, 720), where it is called saime, and in some later sources, such as the Ryōba no san (Eulogy of the Good Horse), by Miyako no Yoshika (834-879).

38 Kakuchō (or kakutei) 穫丁. In addition to the groom (chō), a stableboy (kakuchō) was assigned to each horse. According to RSG, the stableboy was in charge of forage and feeding. 391 shō is equivalent to approx. 0.59 litres.

40 "Rice” is ine 稲, usually meaning "rice on the stalk", not in grains. But RSG confirms that "rice" is to be understood as "half husked rice", and for this reason a unit of capacity has been used.

41 The character used is 豆 (Jp. mame), meaning "beans"; here they are probably soya beans given to horses for their protein value. Only cooked (boiled or roasted) soya beans were used as fodder since raw soya beans contain an enzyme (trypsin inhibitor) harmful to horses.

421 shaku is equivalent to approx. 0.0194 litres.

43 Salt is fundamental for horses as it is rich in the trace minerals needed for their cell cycle. 
the fourth month. As for milk cows, two shō of beans and two $w a^{44}$ of rice shall be given on milking days. ${ }^{45}$

Article 2. Work shifts shall be set up for each stable household ${ }^{46}$ in turns. ${ }^{47}$ The quantity of grass [to levy] as tax in kind ${ }^{48}$ is two-hundred sheaves for adult males, one-hundred sheaves for older males, and fifty sheaves for young males. ${ }^{49}$

Article 3. Upon receiving a request for oils and medicinal plants useful for treating state animals' illnesses, the bureau shall assess in advance the necessary quantity and grant it once every three months. ${ }^{50}$

Article 4. The heads and clerks ${ }^{51}$ of pastures shall be appointed from among honest and strong men of the sixth rank and below, or those who hold merit ranks. They shall be suited to the duties to be carried out. ${ }^{52}$

44 A unit of measurement for small sheaves. 1/10 of a soku.

45 On milk cows and the role of milk in ancient Japan, see Introduction.

46 The stable household was known as a meko (or umako) 馬戸. A ko was a "basic social unit”, established under the Koryō (Law on Households), for production, census taking, and tribute collection. It consisted of one or more families (ke) bound by political-economic interests. The head of the household (koshu 戸主) was responsible for aiding the township and district officials in census taking, field distribution, and tribute collection. Stable households, coming under the Bureau for Horses, were responsible for feeding and training horses and were under the management of a corporation of "horse caretakers" (Umakaibe). On households see Mazzei 1977, from whom I took the expression "basic social unit". See also Dettmer 2010: 28-59; Yoshie, Ijūin, Piggott 2013.

47 The RSG explains that turns are set up according to age.

48 Chō 調 (in Japanese also tsuki or mitsugi) was a craft or produce tax, one of the forms of tribute-taxation levied only on taxable males ( $k a k \bar{o}$, or kachō) instituted by the ritsuryō codes. It was generally payable in cloth and the native products of the region in which a man resided. Tribute in the form of cloth, thread, iron, iron tools, salt, and other local goods was sent to the Ōkurashō (Ministry of Treasure), which was supposed to use the proceeds to provision the government in the capital and to pay officials' salaries.

49 According to art. 6 of the Law on Households, taxable males were divided into three main classes, namely, first-class males (seichō 正丁), i. e. men aged from twenty-one to sixty, secondclass males (jichō 次丁), sixty-one or more years old and first-class males in poor physical condition, and third-class males (chūnan 中男), namely men aged from seventeen to twenty (in 757 this became eighteen to twenty-one). The amount of taxes the men from these three classes paid was in a ratio of 4:2:1. See RR: 226; Mazzei 1977: 66; Dettmer 2010: 31-32; Takeuchi 1988: 139. 50 I translate kanchiku 官畜 as “state animals”. According RGG and RSG, these are exclusively the horses of the Bureau for Horses. Commentaries have pointed out that nothing is said about animals in pastures (maki). The Kekki records that application for pasture animals should be made to the province, and from the province to the higher level.

51 Clerks (chō 帳) were secretaries in charge of compiling documents.

52 Under the ritsuryō codes, a system of ranks that paralleled the normal court ranks but where promotions were based on meritorious performance in military campaigns. See Friday 1992: 66-67. 
Article 5. A head and a clerk shall be assigned to each pasture. ${ }^{53}$ Moreover, two herdsmen ${ }^{54}$ shall be assigned to each herd. ${ }^{55}$ Each herd shall consist of one hundred heads of equine or bovine cattle at pasture. ${ }^{56}$

Article 6. Mares shall be mated from four years of age. ${ }^{57}$ At five years of age they shall foal. Heifers shall be mated from three years of age. At four years of age they shall calve. There shall be sixty newborns per hundred brood females of both species each year. ${ }^{58}$ Should a mare be mated and foal at three years of age, it shall be recorded in a special register.

Article 7. For every two foals or three calves in excess, a reward of twenty soku ${ }^{59}$ of rice shall be bestowed upon the two herdsmen. ${ }^{60}$ A reward of twenty soku of rice shall be bestowed upon the head and the clerk of the pasture respectively for every two foals or three calves extra to the minimum quantity required resulting from the total sum of herds in the pasture over which they have jurisdiction. ${ }^{61}$

Article 8. Each year, ten out of a hundred heads of cattle may die in ordinary conditions. ${ }^{62}$ In the case of death by epidemic, a comparison shall be

53 According to RGG and RSG, also if there were few heads of cattle, a head and clerk still had to be assigned.

54 Herdsmen (bokushi 牧子) were male full-time workers working on a daily basis without rotation.

55 According to the Shuki, only one herdsman was to be assigned for less than fifty heads of cattle, but if there were more than sixty animals (more than fifty for the Ryōshaku), both herdsmen were to be assigned.

56 Commentaries say that foals and calves till the second year of life, as established in art. 10, namely animals without state marking 官, were not to be counted, but after the second year they were to be assigned to other herds.

57 Commentaries say that the season had to be spring. Furthermore, mating took place inside the stables, and the animals were tethered.

58 Commentaries confirm that the number "hundred" does not refer to the herd (consisting of males and females), but to one hundred brood females (母畜), in other words, six newborns per ten females every year.

59 A unit of measurement for bigger sheaves.

60 Twenty soku of rice was equal to the total sum to be divided between the two herdsmen. The RGG suggests that if there was a difference in rank between the two herdsmen, the superior was to receive ten nineteenths of the rice and the subordinate nine nineteenths, but if there was no difference, the twenty soku of rice were to be divided equally.

61 The salary for the heads and clerks of pastures were calculated based on the ratio between the total number of newborns and the number of herds. For example, if the head and the clerk had jurisdiction over two herds of horse, the number of newborns in excess was to be four (two for each herd, or three in one herd and one in the other). RGG also adds that if one of the two officials dies, the entire salary shall be assigned to the living one.

62 In the event of loss exceeding the legally established rate, punishments are prescribed according to the ritsu. More specifically, according to the Kukoritsu (Penal Law on Stables 
made with nearby private pastures. If the death toll is the same, it shall be declared that the loss is due to the epidemic. ${ }^{63}$

Article 9. Should any state equines or bovines at pasture be lost, one hundred days shall be granted to track them down. If, by the end of this period, the heads of cattle are not recovered, the value of the animal at the moment of loss shall be assessed and shall be divided into ten parts. Seven parts of this value shall be required from the herdsmen and three parts from the head and clerk. ${ }^{64}$ If the office is vacant or the man in charge dies, only the quota from the officials currently in office shall be due. If animals from state stables are lost, the foreman $^{65}$ of the stable shall be demoted to head of pasture, and the stablehands ${ }^{66}$ to herdsmen. If, after being lost, the heads of cattle are found, what has been forfeited shall be returned. If an animal dies from negligence [by the people in charge], it shall be replaced by an animal of the same value.

Article 10. In the ninth month of each year, the governor of the province, accompanied by the head of the pasture, shall apply to the foals and calves in pastures that have reached two years of age a marking with the character kan 官, meaning "official", in the upper part of the left thigh of foals and the upper part of the right thigh of calves. Then, after marking, the coat colour and age [of each head of cattle] shall be carefully recorded ${ }^{67}$ on a document in duplicate: one of

and Storehouses), "in all cases of animals that are put out to pasture, if the [number of] deaths or losses of animals is excessive or the quota is not fulfilled, the two herdsmen shall be punished by twenty blows using the light cane for the first animals, increased by one degree for each further three animals. If the degree reaches one hundred blows with the large stick, it shall be increased by one degree for each further twenty animals. The maximum punishment is two years of compulsory penal servitude. Heads and clerks shall be punished according to the total number of animals”. RR: 414-415.

63 In the event of epidemic, the ratio of dead to surviving heads was calculated. The RGG explains that an epidemic was deemed to exist if the ratio of dead to live animals was the same in both state and private pastures (for example, fifty dead heads of cattle out of one hundred in a state pasture and ten heads out of twenty in a private one). The RSG refers to specific decrees in the event of death by natural causes.

64 In this case too, a proportion based on hierarchy was established: according to the Koki, two thirds were due from the senior herdsman and one third from his subordinate; two thirds were due from the head and one third from the clerk.

65 Shūshi 主師.

66 Jichō (or shitei) 飼丁.

67 Animals were registered by coat colour (毛色) and age (歯歳). RSG includes a comment regarding the character used to denote age: "The (Ryō)Shaku says that 'we can determine age from the state of the teeth. Age is therefore also called 'tooth age". The Koki says the same thing. In addition, [the Koki] explains that the expression 毛色 (literally 'fur colour') is the term used to refer to the colour of the animal's coat. This is recorded in Ryōshaku. The Shuki says that 'coat colour and age are just a part (of the rule); also the sex (of the species) is recorded"”. 
the two copies shall remain at the head office of the province, and the other one shall be handed over to a messenger ${ }^{68}$ for delivery to the Council of State.

Article 11. During the first month of each year, ${ }^{69}$ grazed fields shall be burnt slowly, starting from one side of the field, in order to spread even grass growth everywhere. $^{70}$ This rule shall not be applied to fields in exceptional climatic conditions $^{71}$ nor in fields where it is forbidden to light a fire. ${ }^{72}$

Article 12. It is the duty of herdsmen to mark pasture horses. If herdsmen alone are not able [to do so], the governor of the province shall assess the number of extra hands required and shall hire men $^{73}$ from the locality.

Therefore, as the Ryōshaku too explains, the word for "age” (歯歳) includes the character 歯 "teeth", because horse age can be estimated from teeth growth, an old but nearly forgotten practice common even in modern societies. The manual explaining how to determine animal age from teeth is the Qimin yaoshu (Essential Techniques for the Welfare of the People, 544), the best preserved ancient Chinese agricultural text, written by Northern Wei Dynasty official Jia Sixie (5th-6th C.) and most certainly also known in Japan. It consists of ninety-two sections in ten books and provides information on agronomy, horticulture, forestry, sericulture, animal welfare, veterinary science, and food production. It quotes more than 150 books, most of which are lost. Section 56 of Book 6 deals with domestic animals, such as horses, cattle, swine, etc. In addition, several documents on paper or on wooden tablets have the character for "teeth" followed by a number, indicating the age. Other than coat colour and age, the Shuki quoted by RSG also requires markings for the sex (牡牝) of the animal. Also art. 22 of the Kushikiryō (Law on Official Documents), on the format for transit passes (kasho), requires the number of horses or bovines to be recorded, together with their sex, age, and coat colour (其毛生牝馬牛若干疋 頭). For details on establishing age from the teeth, see the critical edition of Qimin yaoshu (Miao 1998: 398). On the reception and circulation of Qimin yaoshu in ancient Japan, see Manieri 2014. On documents regarding horses and bovines, see Manieri 2012, forthcoming 2019. On the Kushikiryō, see RR: 365-406; Migliore 2011; Dettmer 2010.

68 The chōshūshi 朝集使 was an agent who carried reports and petitions from the provincial headquarters to the capital during the Nara and Heian periods. There are four categories of provincial messengers, known collectively as the yodo no tsukai. See Hérail 1966.

69 Some commentaries add also "by the second month".

70 A quotation from the Kekki adds that from the eleventh month, the horse shall be "raised on a tether" (tsunagigai 繋飼), i. e. inside the stable and eating hay; from the fourth month, the horse shall be "raised in freedom" (hanachikai 放飼) eating fresh grass in the open air.

71 RSG explains that these exceptional climatic conditions are the northern territories, which become warmer later, or the southern territories, which become warmer much earlier.

72 RSG clarifies that these are mountain woods and bamboo groves.

73 Commentaries specify that men are hired by means of irregular forced labour (zōyo 雑姼), i.e. the labour carried out on public works or miscellaneous work at government offices in a province upon the orders of the governor of the province. Such labour is regulated by art. 37 of the Buyakuryō (Law on Taxation and Corvées). The men involved should be hakutei 白丁, ordinary simple adults without rank or official duties, who can be considered available. See RR: 261. 
Article 13. Horses raised on pastures and deemed suitable for riding shall be attached to the regiment. ${ }^{74}$ These horses shall be placed in the care of conscripted soldiers ${ }^{75}$ in their home province [who come] from wealthy families capable of caring for them. They shall be used as packhorses ${ }^{76}$ or for other unspecified services. ${ }^{77}$

Article 14. Post stations shall be established every thirty $r i^{78}$ along the various roads. ${ }^{79}$ In inaccessible fields and in places where there is no water or grass, post stations shall be established regardless of the distance. Riding equipment, raincoats, and hats, ${ }^{80}$ etc., shall be provided according to the number of horses kept at the post station.

Article 15. A post station head ${ }^{81}$ shall be appointed for each station. He shall be selected from among large, skilled households with practical experience in charge of post roads. ${ }^{82}$ Once appointed, he shall remain in charge

74 The provincial regiments (gundan 軍団) were administrative organizations, not standing garrisons or tactical units. They were constituted of provincial troops and differed in size because they were made up of one third of the first-class males in the territory under the jurisdiction of a specific army division. See Friday 1992: 13-20.

75 "Conscripts" (heishi 兵士) were enrolled in one of the provincial regiments. One in three adult males from every household $(k o)$ had to be enrolled in the regiment. Friday 1992: 13-20. 76 For example, they were used to transfer sakimori around the country. These were special garrison troops drawn from the provincial regiments and stationed in the southwestern frontier region as border guards.

77 According to the RSG, these horses were therefore to be regarded as "military horses" (hyōme or heiba 兵馬).

78 One $r i$ was equivalent to approximately $0.54 \mathrm{~km}$.

79 The seven state roads (shichidō), i. e. the seven circuit highways that connect the provinces to the capital district (Kinai). They are grouped into: "large road", the San'yōdō (running west along the northern side of the Seto Inland Sea), "medium roads", i. e. the Tōkaidō (running east along Japan's Pacific coast) and the Tōsandō (northeast through the Japanese Alps), "small roads", i. e. the Hokurikudō (northeast along the Sea of Japan coast), the San'indō (west along the Sea of Japan coast), the Nankaidō (south to the Kii Peninsula and the islands of Awaji and Shikoku), and the Saikaidō (towards Kyūshū, the western island).

80 “Raincoats” translates 峦 (Ch. suo, Sino-Jp. sa, Jp. mino), denoting the straw used to produce raincoats. The Koki explains that according to commentaries on the Shijing (Classic of Poetry, 7th C. BCE), the suo/mino was intended to give protection from the rain, whereas hats 笠 (Ch. li, Sino-Jp. ryū, Jp. kasa) were to provide shade from the sun. According to a note in the Koki, riding equipment was provided by the government, but raincoats and hats were provided directly by the officers at the station (ekishi 駅子).

81 Ekichō (駅長).

82 The "households in charge of post roads” (yakko 駅戸) were households whose duty was to look after the post horses and post ferries at the post stations. The government granted them "post rice fields” (ekiden 駅田) for sustenance. These were tax-free rice fields (fuyusoden 不輸祖田). 
lifelong. He shall be replaced in the event of death, old age, and illness, or if his family ${ }^{83}$ sinks into poverty. Any missing horses and equipment shall be ascribed to the outgoing official on the day of succession. This rule shall not be applied in the event of verified plundering raids by savage tribes in the neighbouring areas and the impossibility of effective measures to deal with them.

Article 16. There shall be twenty post horses ${ }^{84}$ for large roads, ten for medium roads, and five for small roads. ${ }^{85}$ In less frequented places, the provincial official shall assess how many animals are to be positioned, without necessarily adhering to [the terms] of this regulation. The horses shall be cared for by robust and strong men. A medium to middle-sized household ${ }^{86}$ shall be responsible for the sustenance of one horse. A missing horse shall be compensated for by a quantity of rice (produced in the fields belonging to the station). ${ }^{87}$ Moreover, each district shall have five relay horses, ${ }^{88}$ all of which shall be used as official horses. ${ }^{89}$ If unavailable, it shall be permitted to replace them with the use of state goods. These horses shall be assigned to men from wealthy families, who shall feed them and hold them ready for official transport purposes. $^{90}$

Article 17. In stations along watercourses, ${ }^{91}$ where horses cannot be assigned, after assessing the intensity of traffic, a maximum of four and a minimum of two waterborne craft shall be provided. A labourer shall be assigned for each vehicle. Chiefs of post stations shall be employed under the same conditions as on mainland roads.

83 "Family" is my translation of ie (家), meaning a patrilineal stem family. See Mazzei 1977: 58; Yoshie, Ijūin, Piggott 2013: 367.

84 “Post horses” translates yakume or ekiba (駅馬). See Introduction.

85 For the classification of state roads see Note 79 above.

86 Here, "household" is a term taken from a classification according to economic strength, as per art. 6 of the Law on Taxation and Corvées, rather than according to the number of working males belonging to it. Therefore, a medium to middle-sized household (chūchūko) belongs to the 5th rank on a scale of nine. See RR: 253; Dettmer 2010: 97-99.

87 Yakudō or ekitō (駅稲) is the rice harvest from the post station fields (ekiden) produced for post station expenses.

88 “Relais horses” translates denme or denba (伝馬). See Introduction, also for the distinction between these and yakume.

89 Kanba (官馬).

90 The RSG defines "official transportation" as that of a provincial official moving to his provincial headquarters, or the transfer of prisoners.

91 A station along watercourses (suieki 水駅) is a horseless station along a watercourse, such as a river or a canal but not by the sea, as specified in the commentaries. 
Article 18. Post horses and relais horses shall be changed at the next station, otherwise transit shall not be permitted. This regulation shall not be applied if horses are not available. ${ }^{92}$

Article 19. The official horses assigned to the regiments shall be trained by a designated soldier ${ }^{93}$ in an area within ten miles of his own village, if he so wishes. ${ }^{94}$ Should the horse die for some irrational reason while in the care of the family, it shall be replaced by another within sixty days. This regulation shall not be applied if the soldier dies and his family is impoverished and unable to offer compensation.

Article 20. Provincial officials shall inspect post horses and relais horses annually. Should the animals be too aged or sick and thus incapable of being used as transport, they shall be sold. If the price [obtained] is low, [the income from the sale of the] post horses shall be supplemented with rice produced in the post station fields; relais horses shall be replaced by official goods.

Article 21. If envoys ${ }^{95}$ need to use post or relais horses and these are not available, private horses shall be used. Should these private horses die while being used by envoys, the government must refund [their value].

Article 22. State officials using relais horses shall have access to all state goods and provisions according to their rank until they reach their destination. Provisions shall be furnished every three stations. In arduous mountainous areas or very remote places, they shall be provided at each station.

Article 23. If beasts [not belonging to official pastures] are found in a district of any province, all the owners of that district shall be summoned. If the owner is not found within six months, the horses shall be used as relais horses. ${ }^{96}$ If a horse that is found is not used as a relais horse because there is already a surfeit of horses, it shall be sold, and the monies obtained shall become treasure of state. If the horse is found in the capital and the owner is not found within six months, the animal shall be sold directly, and the monies obtained shall be sent to the Office for Stolen Goods. ${ }^{97}$ In any case, if the owner is subsequently found and ownership is ascertained, the proprietor shall be reimbursed for the original value. ${ }^{98}$

92 According to the RGG, in this case the horse could be used for a distance longer than that between two stations.

93 According to the RSG, the honjū (本主) was a soldier designated to take care of a horse.

94 The RSG states that the area of jurisdiction extends for ten miles in the case of an animal's death.

95 Kūshi or kōshi (公使).

96 The Kekki clarifies that "beasts" means "horses". Bovines are to be sold directly.

97 Aganaimono no tsukasa or zōshokushi (䁍贖司) is the office of the Gyōbushō (Ministry of Justice) in charge of stolen goods.

98 Concerning documents relating to this article, see Manieri 2012, forthcoming 2019. 
Article 24. If goods are found, a provincial official must be notified within five days. If these goods are found within the capital area, and if no owner is found, they shall be sent to the Capital Offices. ${ }^{99}$ If requisition becomes necessary before the given deadline, the goods shall be put up for sale. If the goods are found outside the capital, refer to the previous article.

Article 25. Registers of state and private horses and cattle shall be delivered to a messenger for delivery to the Council of State.

Article 26. Skin, brain, ${ }^{100}$ horns, and gall bladder ${ }^{101}$ shall be removed from dead state animals' remains. Gallstones ${ }^{102}$ found in the dead bovines shall be stored separately.

Article 27. Should a handler cause the death of official or private horses or bovines used for public affairs, compensation shall be awarded if it is evident that the user is not at fault. ${ }^{103}$ Skins and flesh shall be sold by the local official, and the obtained monies shall be received by the official himself. If the beast dies due to [the handler's] negligence, he shall pay the equivalent value of the skins and flesh. ${ }^{104}$

99 The Kyōshiki (京職), Capital Offices, are the two offices - one for the eastern part (Sakyō) and one for the western part (Ukyō) - which administrate the affairs of the capital, including household registration (koseki) and the police.

100 The RSG clarifies that "brain" means "equine brain".

101 The RSG clarifies that "bladder" means "bovine bladder". Horses are monogastric organisms without a gall bladder, whose gall is secreted directly into the small intestine. In RSG, Koki quotes Zhuangzi (Master Zhuang, circa 4th C. BCE) to explain that the gall bladder could be defined as "the government of the liver" and related to the White Tiger in the theory of the five phases. Nevertheless, in some medieval handscrolls dedicated to horse healing, such as the Anzairyū ba'i emaki (Illustrated Handscroll on Horse Healers of the Anzai School, 1464), the horse is associated with gorintō theory, which, in the five phases theory, relates horse viscera to five phases, so the horse too is said to have a gall bladder. See Mitsui 1994: 456-457.

102 Gallstones (or bezoars) are called “cattle yellow" (牛黄, Ch. niu huang, Sino-Jp. gyūkō) and are pathological concretions. However, when they occur in the gall bladder bile of bovines, they are regarded as a rare and valuable product with magical healing power to remove toxins from the human body. Gallstones were first recorded and described in the Shennong bencaojing (Classic of the Divine Farmer's Materia Medica, 3rd C. BCE), an older text on medical plants no longer extant but handed down via indirect tradition. In Chinese traditional medicine, gallstones are used to treat fever, convulsions, sore throats, etc. See Schafer 1985: 191.

103 Dead animal meat was probably eaten in pre-ritsuryō Japan. The prohibition of consuming the meat of bovines, horses, dogs, chicken, and monkeys was ordained by sovereigns Tenmu and Shōmu. See the Introduction for more detailed information.

104 The last character in the article 陪 (Ch. pei, Sino-Jp. be or hai/bai) has the basic meaning of “compensation”. In RGG: 278, an interlinear gloss in Vernacular reads it mite (followed by the grammatical suffix shimeyo), which is the mizenkei of the verb mitsu (充つ), meaning "satisfying demands, meeting the requirements". This reading confirms the idea of "compensation". Therefore, the compound 徵陪, as also explained by RR: 420, refers to the necessity of 
Article 28. If an official animal becomes fatigued ${ }^{105}$ during a journey and is unable to carry on, it shall not be allowed to proceed and shall stop over at the nearest district or provincial headquarters. Food and care shall be provided. Grass and medicinal plants shall be provided by the government. On the day of its recovery, an envoy shall be sent to organize its return to the office ${ }^{106}$ responsible for the place where it came from. If the animal dies, the office of that place shall be in charge of the procedures.

\section{References}

\section{Primary sources}

ES: Kuroita, Katsumi 黒板勝美 (ed.) (1955): Kōtaishiki. Kōninshiki. Engishiki 交替式・弘仁式・ 延喜式. Tōkyō: Yoshikawa kōbunkan.

KZ: Kuroda, Akira 黒田彰/Gotō, Akio 後藤昭雄/Tōno, Haruyuki 東野治之/Miki, Masahiro 三木雅 博/Yamazaki, Makoto 山崎誠 (eds.) (1997): Kuchizusami chūkai 口遊注解. Tōkyō: Bensei shuppansha.

MYS: Kojima, Noriyuki 小島憲之/Kinoshita, Masatoshi 木下正俊/Tōno, Haruyuki 東野治之 (eds.) (1995): Man'yōshū 万葉集. Vol. 3. Tōkyō: Shōgakukan.

NR: Izumoji, Osamu 出雲路修 (ed.) (1996): Nihon ryōiki 日本霊異記. Tōkyō: Iwanami shoten.

NS: Sakamoto, Tarō 坂本太郎/lenaga, Saburō 家永三郎/Inoue, Mitsusada 井上光貞/Ōno, Susumu 大野晋 (eds.) (1965): Nihon shoki 日本書紀. Vol. 2. Tōkyō: Iwanami shoten.

RGG: Kuroita, Katsumi 黒板勝美 (ed.) (1939): Ryō no gige 令義解. Tōkyō: Yoshikawa kōbunkan. RR: Inoue, Mitsusada 井上光貞/Seki, Akira 席晃/Tsuchida, Naoshige 土田直鎮/Aoki, Kazuo 青 木和夫 (eds.) (1976): Ritsuryō 律令. Tōkyō: Iwanami shoten.

RSDK: Kuroita, Katsumi 黒板勝美 (ed.) (1959): Ruiju sandai kyaku. Kōninkyakushō 類聚三代 格・弘仁格抄. Tōkyō: Yoshikawa kōbunkan.

RSG: Kuroita, Katsumi 黒板勝美 (ed.) (1940): Ryō no shūge 令集解. Tōkyō: Yoshikawa kōbunkan.

SNG: Aoki, Kazuo 青木和夫/Inaoka, Kōji 稲岡耕二/Sasayama, Haruo 笹山晴生/Shirafuji, Noriyuki 白藤礼幸 (eds.) (1989-1998): Shoku Nihongi 続日本紀. (5 voll.). Tōkyō: Iwanami shoten.

WMS: Nakada, Norio 中田祝夫 (ed.) (1978): Wamyōruijushō. Genna sannen kokatsujiban nijikkanbon 倭名類聚抄一元和三年古活字版二十巻本. Tōkyō: Bensei shuppansha.

compensating the value of the dead beast. For a discussion on this compound see Dettmer 2010: 435.

105 The character used here is 贏 (Ch. lei, Sino-Jp. rui), which, according to a note in the Ryōshaku is a synonym for 瘦 and 病, namely “exhausted" or “ill”.

106 District, province, or post station office. 


\section{Secondary references}

Dettmer, Hans A. (2009): Der Yōrō-Kodex. Die Gebote. Einleitung und Übersetzung des Ryō no gige. Buch 1. Wiesbaden: Harrassowitz Verlag.

Dettmer, Hans A. (2010): Der Yōrō-Kodex. Die Gebote. Einleitung und Übersetzung des Ryō no gige. Bücher 2-10. Wiesbaden: Harrassowitz Verlag.

Friday, F. Karl (1992): Hired Swords. The Rise of Private Warrior Power in Early Japan. Stanford: Stanford University Press.

Friday, F. Karl (2014): “The Statute on Military Defense [Gunbōryō 軍防令]”. In: The Project for Premodern Japanese Studies. Ritsuryō Translation Project. Directed by Joan Piggott available on http://www.uscppjs.org/resources/\#/ritsury-translation-project/last consulted: $(8 / 31 / 2018)$

Harris, Marvin (1998): Good to Eat: Riddles of Food and Culture. Long Grove, Illinois: Waveland Press.

Hérail, Francine (1966): Yodo no tsukai ou le système des Quatre Envoyés. Paris: Presses universitaires de France.

Ikeda, On 池田温 (ed.) (1997): Tō rei shūi ho. Fu tō-nichi ryōryō taishō ichiran 唐令拾遺補一附唐 日両令対照一覧. Tōkyō: Tōkyō daigaku shuppankai.

Kamo, Giichi 加茂儀一 (1973): Kachiku bunkashi 家畜文化史. Tōkyō: Hōsei daigaku shuppankyoku.

Manieri, Antonio (2012): “Wamyōruijushō 'gyūba no ke’ mon to Narachō no kakyū kanjinsō. Kangoshō, Yōshi kangoshō, Benshiki rissei o megutte”『和名類聚抄』牛馬毛門と奈良朝 の下級官人層一『漢語抄』『楊氏漢語抄』『弁色立成』をめぐって. Higashi Ajia hikaku bunka kenkyū 11: 72-85.

Manieri, Antonio (2014): “La veterinaria nel Giappone antico: note su testi e lessico nel periodo dello Stato retto dai codici”. In: Riflessioni sul Giappone antico e moderno. Edited by Matilde Mastrangelo, Luca Milasi, and Stefano Romagnoli. Rome: Aracne, 305-327.

Manieri, Antonio (forthcoming 2019): "Document Production by Low-rank Officials in Ancient Japan: Notes on Some Texts on Wooden Tablets about Public Advice". In: Textual and Material Craftmanship: What Does Copying a Manuscript Mean? Edited by Antonella Brita, Giovanni Ciotti, Florinda De Simini, and Amneris Roselli. Naples: UniorPress.

Mazzei, Franco (1977): I moduli sociali di base nel Giappone antico. Struttura e funzioni delle famiglie (ko 戸) dei registri anagrafici conservati nello Shōsōin, Supplement 13 to Annali dell'Istituto Universitario Orientale 37.4.

Miao, Qiyu 繆啟愉 (ed.) (1998): Qimin yaoshu jiaoshi 齊民要術校釋. Beijing: Nongye chubanshe. Migliore, Maria Chiara (2011): I documenti ufficiali del periodo di Nara (710-784). Rome: Edizioni Nuova Cultura.

Mitsui, Takaosa 三井高孟 (1994): “Emaki ni himerareta rekishi” 絵巻に秘められた歴史. In: Uma no bunka sōsho. Vol. 7. Bagaku. Uma o kagaku suru 馬の文化叢書第七巻一馬学・馬 を科学する. Edited by Matsuo Shin'ichi 松尾信一. Yokohama: Baji bunka zaidan, 442-462.

Muraoka, Kaoru 村岡薰 (1984): “Ritsuryō kokka no kanboku hyōme seisaku to sono igi” 律令国 家の官牧兵馬政策とその意義. In: Ritsuryōsei to kodai shakai 律令制と古代社会.

Edited by Takeuchi Rizō sensei kijūkinen ronbunshū hakkōkai 竹内理三先生喜寿記念論文 集刊行会. Tōkyō: Tōkyōdō shuppan, 84-109.

Niida, Noboru 仁井田侾 (1964 [1933]): Tō rei shūi 唐令拾遺. Tōkyō: Tōkyō daigaku shuppankai. 
Ooms, Herman (2009): Imperial Politics and Symbolics in Ancient Japan: the Tenmu Dynasty, 650-800. Honolulu: University of Hawai'i Press.

Sakamoto, Tarō 坂本太郎 (1928): Jōdai ekisei no kenkyū 上代駅制の研究. Tōkyō: Shibundō.

Sansom, George B. (1932): "Early Japanese Law and Administration. Part I”. Transactions of the Asiatic Society of Japan (2nd Series) 9: 67-109.

Satō, Kentarō 佐藤健太郎 (2016): Nihon kodai no maki to basei kanshi 日本古代の牧と馬政官 司. Tōkyō: Hanawa shobō.

Satō, Makoto 佐藤信 (1997): Nihon kodai no kyūto to mokkan 日本古代の宮都と木簡. Tōkyō: Yoshikawa kōbunkan.

Schafer, Edward H. (1985): The Golden Peaches of Samarkand. A Study of T'ang Exotics. Berkeley and Los Angeles: University of California Press.

Takeuchi, Rizō 竹内理三 (1988): "Documents of Local Administration in the Nara Period: the Household Registers and the Tax Registers". Foreword, translation and notes by Maria Chiara Migliore. In: Tang China and Beyond. Studies on East Asia from the Seventh to the Tenth Century. Edited by Antonino Forte. Kyōto: Scuola di studi sull'Asia Orientale, 125-161.

Tanaami, Hiroshi 田名網宏 (1995): Kodai no kōtsū 古代の交通. Tōkyō: Yoshikawa kōbunkan.

Verschuer, Charlotte von (2008): "Les voies de communication et les transports à l'époque de Heian (784-1185)”. In: Atlas historique de Kyoto. Analyse spatiale des systèmes de mémoire d'une ville, de son architecture et de son paysage urbain. Edited by Nicolas Fiévé. Paris: UNESCO, L’Amateur, 95-100.

Yamaguchi, Hideo 山口英男 (1986): “Hachi-kyūseiki no maki ni tsuite”八・九世紀の牧につい て. Shigaku zasshi 95.1: 1-37.

Yoshie, Akiko 義江明子/ljūin, Yōko 伊集院葉子/Piggott, Joan R. (2013): “Nihon ryō ni miru jendā (Sono 1) Koryō 日本令にみるジェンダーーその（1）戸令. Gender in the Japanese Administrative Code (Part 1) Laws on Residence Units". Teikyō shigaku 28: 418-317. 